\title{
IZKUSTVENO UČENJE KOT PRAKSA IN TEORIJA IZOBRAŽEVANIA IN USPOSABLJANIA STROKOVNIH DELAVCEV V VRTCU TRNOVO
}

Mojca Garvas

Vrtec Trnovo, Ljubljana

\section{POVZETEK}

Kako se predšolski otrok uči? Kakšno znanje je za otroka smiselno? Kakšna vseživljenjsko pomembna temeljna znanja potrebuje otrok? Kako mu strokovni delavci v vrtcu lahko pomagamo, da bo zgradil takšno znanje, ki mu bo služilo pri startu v učenju in življenju v prihodnosti? Iskanje odgovorov na ta in podobna vprašanja je življenjsko delo in pot našega vsakdanjega pedagoškega razmišljanja in ustvarjanja. Kot pravi Bečaj (2006), sta vzgoja in izobraževanje vedno usmerjena v prihodnost, zato je še kako pomembno, da mlade rodove pripravimo na svet, ki šele nastaja in za katerega nikoli ne vemo dobro, kakšen bo. Vvse bolj kompleksnih in nepredvidljivih situacijah sodobni vrtec potrebuje vzgojitelja, ki otroku pomaga pridobivati znanja in veščine, ki jih bo potreboval v prihodnosti. Potrebuje strokovno usposobljenega in problemsko razmišljujočega vzgojitelja; učečega se vzgojitelja, ki se zaveda, da današnje znanje že jutri lahko zastara. Pri tem ima pomembno vlogo izkustveno učenje in izobraževanje, saj sodobno pojmovanje učenja pomeni predvsem interpretacijo izkušenj. Izkušnja je jedro učenja.

Ključne besede: izkustveno učenje in izobraževanje odraslih, izkustveno učenje predšolskih otrok, vseživljenjsko učenje in izobraževanje

\section{EMPIRICAL LEARNING AS A PRACTICE AND THEORY IN ADULT EDUCATION IN THE TRNOVO KINDERGARTEN - ABSTRACT}

How does a preschool child learn? What knowledge should he gain? What type of fundamental knowledge does he need? How can professional workers in the kindergarten help children acquire the knowledge they need to start learning? Searching for answers to these and similar questions is a lifelong task, involving our daily pedagogical thinking and creating. According to Bečaj (2006), education is always future oriented, that is why it is very important to prepare young generations for a world which is presently only taking shape and can not be predicted. In the increasingly complex and unpredictable situations the modern kindergarten needs a pedagogue who helps children to acquire the essential knowledge and skills they will need in the future. They need a professionally qualified and considerate pedagogue; one who is conscious of the fact that today's knowledge will be obsolete tomorrow. Empirical learning and education play a very important role in this process, as learning is today understood as interpretation of the experience, the experience being the essence of learning.

Keywords: experience based learning and adult education, experience based learning in preschool children, lifelong learning and education

\section{UVOD}

V Vrtcu Trnovo izhajamo iz prepričanja, da se tako predšolski otrok kot tudi vzgojitelj naučita največ takrat, ko dejavnost opravita sama. Menimo, da se ničesar v življenju ni mogoče zares dobro naučiti, razumeti in znati, če tega ne preizkusimo v praksi. Pri tem je pomembno, da znamo o situacijah in dogodkih razmišljati, razglabljati in jih reflektirati. Šele potem se znamo iz izkušenj tudi učiti.

Ker so izkušnje učinkovita podlaga za učenje in izobraževanje, je namen prispevka osvetliti pomen in koristi izkustvenega učenja, tako za otroka kot tudi za strokovnega delavca. Ob tem se navezujem na izkustveno učenje in izobraževanje strokovnih delavcev v Vrtcu Trnovo, saj mora biti strokovni delavec najprej sam usposobljen, da lahko usposobi oziroma izobrazi otroke; da jim lahko ponudi nova področja izkušenj. V nadaljevanju ugotavljam, kako izbrane strokovne delavke v Vrtcu Trnovo, kjer ima izkustveno učenje središčno vlogo $\mathrm{v}$ procesu učenja in izobraževanja, razumejo izkustveno učenje in kako se to kaže v praksi.

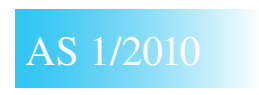




\section{POIMOVNA OPREDELITEV IZKUSTVENEGA UČENIA IN IZOBRAŽEVANJA}

Izkustveno učenje se je razmahnilo $\mathrm{v}$ zadnjih desetletjih kot odgovor na učenje, ki je zasnovano na knjigah; slednje razvija predvsem abstraktno znanje. Izkustveno učenje je način, kako se povežejo teorija in praksa, izkustveno spoznavanje resničnosti in konkretna akcija, in to ne glede na starost udeležencev. Bistveno in osrednjo vlogo ima osebna izkušnja, saj je za izkustveno učenje značilno, da se najbolje učimo, če nekaj naredimo sami.

$\mathrm{V}$ literaturi in praksi se pojavljata tako izraz izkustveno učenje kot izraz izkustveno izobraževanje; večina avtorjev uporablja termin izkustveno učenje, nekateri govorijo o izkustvenem izobraževanju. Krajnc (1998) meni, da ni moteče, če se pojavljata oba izraza, saj je to odvisno od tega, kaj hoče posameznik poudariti. Sama v prispevku uporabljam tako termin učenje kot termin izobraževanje, kjer učenje razumem kot vsakršno nenačrtno sprejemanje informacij, ki povzroča spremembe pri posamezniku, izobraževanje pa kot organizirano, strukturirano in načrtno aktivnost posameznika, da pridobi nove informacije, novo znanje. Izobraževanje vključuje ciljnost, namenskost, medtem ko je učenje imanentna človekova vseživljenjska dejavnost. Večina psiholoških definicij učenja poudarja, da je učenje relativno trajno spreminjanje posameznika (njegovega znanja, spretnosti, navad, stališč, prepričanj in ravnanj) $n a$ podlagi izkušenj. V najširšem smislu je vsako učenje izkustveno, saj gre za progresivno spreminjanje posameznika na podlagi izkušenj. $\mathrm{V}$ povezavi izkušnje in učenja se srečamo $\mathrm{z}$ opredelitvijo izkustvenega učenja, kjer je izkustveno učenje proces, $v$ katerem poskušajo posamezniki v sodelovanju z drugimi oblikovati smisel na podlagi situacije, ki se je zavedajo, in se zavzemajo, da bi si ta smisel zapomnili in rezultate vključili v svoje življenjsko izkustvo. Življenjsko izkustvo v tem primeru razumemo kot celotnost naših izkušenj (Jarvis, 203: 10). Kolb (v Mijoč, 1995: 109), eden od najpomembnejših teoretikov tega področja, opredeljuje učenje kot proces, pri katerem se znanje oblikuje oziroma ustvarja (kreira) s transformacijo izkušenj. Zanj je izkustveno učenje vsako učenje v neposrednem stiku z realnostjo, ki jo proučuje. Gre za neposredno srečanje s pojavom, ne za razmišljanje o takem srečanju ali o možnosti, da bi nekaj naredili v resnični situaciji. Kolb izkustveno učenje opredeli kot proces, kjer se znanje ustvarja s pretvorbo izkušnje. Njegov model izkustvenega učenja zajema temeljne procese izkustvenega učenja, in sicer: konkretno izkušnjo, razmišljujoče opazovanje, abstraktno razmišljanje in preizkušanje novih zamisli. Proces izkustvenega učenja je povezan $s$ formalnim in neformalnim učnim okoljem, v katerem se vedenje ustvarja prek transformacij izkušenj. Posameznik je lahko v procesu izkustvenega učenja sam ali pa $v$ interakciji z drugimi ljudmi. Nekateri posamezniki se uspešneje učijo tako, da se učenje začne pri konkretni izkušnji, drugi pa tako, da začnejo na stopnji abstraktne konceptualizacije, kar je odvisno od učnega procesa. V izkustvenem učenju ni pomembno, na kateri stopnji začnemo, pomembno je, da se uresniči vsaka izmed stopenj (prav tam). Mijoč (1995) izkustveno učenje opredeli kot ustvarjalni proces. Pravi, da to ni učenje na podlagi poskusov in napak; to tudi ni verbalno učenje ali memoriranje. Je proces ustvarjalnega spreminjanja dojete situacije $\mathrm{v}$ novo spoznanje; je spoznanje, ki je utemeljeno na lastni izkušnji in lastnem razmišljanju, na tem izhodišču pa posameznik išče možnost aplikacije v praksi, ko dejansko v praksi preizkuša svoja spoznanja.

Izkustveno učenje temelji na konkretnih osebnih $i z k u s ̌ n j a h$. V nove izkušnje človek vstopa z vsem svojim predznanjem, uporabnimi teorijami, s celotno svojo osebnostjo. Zato je tudi posamezna 
Termin izkustveno učenje se uporablja v najrazličnejših kontekstih: za individualno učenje, za učenje $\mathrm{v}$ sproščenem okolju in tudi za tehniko učenja $v$ formalnem in neformalnem izobraževanju. Lahko ga definiramo kot model učenja, ki se začne z izkušnjo, tej sledi refleksija, diskusija, analiza in evalvacija izkustva. Redko se človek uči iz izkušnje, če je ne ovrednoti in če ji ne pripiše pomena znotraj okvira svojih ciljev, ambicij in pričakovanj. Šele s konkretnimi poskusi, s praktično dejavnostjo človek spreminja zunanji svet in hkrati tudi samega sebe. Temeljni kategoriji izkušnje sta kontinuiteta in interakcija, ki sta hkrati tudi kriterija za kakovost in izobraževalno vrednost izkušnje. Kontinuiteta pomeni skladnost preteklih izkušenj s sedanjimi ali prihodnjimi dogodki (vsaka izkušnja živi dalje v naslednjih izkušnjah). Interakcija pa pomeni, da ima vsaka izkušnja svojo objektivno, zunanjo in subjektivno ali notranjo dimenzijo.

situacija za vsakega človeka lahko povsem drugačna izkušnja, vsakdo doživlja situacijo drugače, glede na svoje prejšnje izkušnje. Za uspešno izkustveno učenje je pomembno, da oseba razvije sposobnosti opazovanja, logičnega razmišljanja in rezoniranja, da zmore v mislih načrtovati in se lahko pametno in smiselno odloča med več možnimi dejavnostmi. Lastnosti, ki jih razvija oseba, ki se veliko nauči na lastnih izkušnjah, so: samostojnost, samospoštovanje, samozavest, radovednost, odprtost, sodelovanje, razmišljanje o svetu in iskanje smisla (Mijoč, 1995, 1999). Tudi Marentič Požarnik (1992) izkustveno učenje opredeli kot tisto, ki pomaga razvijati sposobnosti, ki jih ljudje potrebujemo in jih bomo potrebovali tudi v prihodnosti, in sicer: sposobnost prožnega prilagajanja novim okoliščinam, osebna avtonomija, občutljivost do sebe in drugih, sposobnost komunikacije in sodelovanja, zmožnost celostnega dojemanja, sinteze in integracije. Gre za zmožnost, da se znajdemo v nepredvidljivih kompleksnih socialnih situacijah, v katerih ni enega vnaprej opredeljenega pravilnega odgovora oziroma rešitve. Pri izkustvenem učenju se ne ustvarjajo že znane stvari iz preteklosti, ampak se učimo predvidevanja prihodnosti.

Večina teorij o izkustvenem učenju zajema in razlaga učenje v vseh življenjskih obdobjih. Vendarle pa je, kot pravi Mijoč (1995), izkustveno učenje odraslih opredeljeno drugače kot pri otrocih. Otrokova primarna dejavnost je učenje, primarna dejavnost odraslega pa je produktivna dejavnost, ki mu omogoča ekonomsko, psiho-socialno in fizično stabilnost.

\section{IZKUSTVENO UČENJE PREDŠOLSKIH OTROK}

Učenje predšolskega otroka temelji na neposredni dejavnosti in pridobivanju konkretnih izkušenj. Za otroka smiselno učenje izhaja iz njegovih predhodnih izkušenj ter možnosti povezovanja novih izkušenj s starimi. Njegova izkušnja mora biti konkretna, oprijemljiva, dojemljiva čutilom in dosegljiva njegovemu delovanju, saj se otrokom konkretna izkušnja mnogo trajneje vtisne $\mathrm{v}$ spomin kot kakršnokoli drugačno učenje. To še posebno velja za mlajše otroke. Učenje, v katerem sodelujejo $z$ več svojimi čutili, je učinkovitejše, zanj so tudi mnogo bolj motivirani. Za razvoj talentov in sposobnosti potrebujejo otroci bogato okolje, veliko izkustvenih doživetij, fizične in socialne aktivnosti ter motivacijsko spodbujanje, ki jim omogočajo raziskovati, oblikovati in predvsem razširiti njihovo znanje.

Otroci se učijo izkustveno, iz realne situacije. Predšolske izkušnje temeljijo na otrokovi neposredni interakciji z materiali, ljudmi in dogodki. Aktivnost je namreč najbolj priljubljen način učenja majhnega otroka $\mathrm{v}$ primerjavi $\mathrm{s}$ posredovanimi izkušnjami, ki jih prinesejo besede ali slike. Naloga odraslih pri tem je, da jih spodbujamo, da vstopajo $\mathrm{v}$ interakcije z drugimi in da problemske situacije rešujejo samostojno.

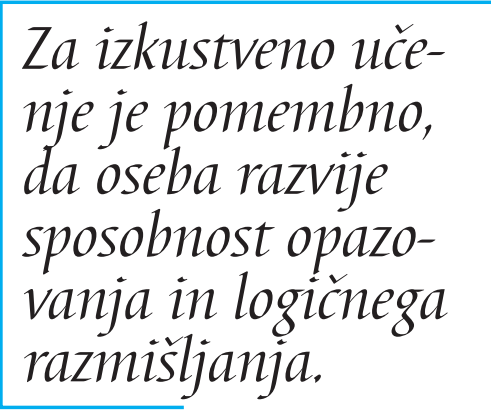

Za izkustveno ucenje je pomembno, da oseba razvije sposobnost opazorazmisljanja. 
Pomembno je upoštevati (Bredekamp in Rosegrant, 1993: 13-17), da:

- se otroci najbolje učijo, ko imajo zadovoljene fizične potrebe, se počutijo varne in zaščitene,

- otroci konstruirajo znanje,

- se učijo skozi socialno interakcijo z odraslimi in drugimi otroki,

- se otrokovo učenje reflektira $v$ ponavljajočem se ciklu, ki se začne z zavedanjem, nadaljuje $\mathrm{z}$ raziskovanjem, odkrivanjem, poizvedovanjem in konča $\mathrm{z}$ uporabo,

- otroci se učijo skozi igro,

- otrokov interes in »potreba po vedenju« motivirata učenje,

- razvoj in učenje se pri vsakem posamezniku razlikujeta.

Bredekamp in Rosegrant (1993: 32) menita, da je kurikulum za otroke smiseln, če:

- temelji na vedenju o tem, kako se otroci uči$j o$, in upošteva cikel učenja,

- upošteva otroka v celoti (razvoj, družbeni in kulturni kontekst) in je osredotočen na otroka,

- zagotavlja globino razumevanja in promovira pojmovni razvoj skozi integracijo izkušenj,

- je individualno primeren, temelji na otrokovih potrebah in interesih,

- izhaja iz baze znanj posameznih predmetnih področij in ima intelektualno integriteto,

- rezultira iz interaktivnega učenja.

Da se lahko otrok nekaj novega nauči, se mora tega tudi zavedati. Proces se dogaja skozi čas in odseva dogajanje, v katerem učenje poteka v neformalni obliki, skozi spontano dejavnost in otrokova pravila, pa do bolj formalnega, razširjenega in bogatejšega konvencionalnega pojmovnega sistema. Cikel prehaja iz primarno raziskujočega odkrivanja do bolj ciljno vodenega, od iskanja, poizvedovanja, inventivnosti do konvencionalnosti. Ta proces je značilen za vsa razvojna področja: socialno, čustveno, motorično in kognitivno (prav tam).

Učenje majhnih otrok je rezultat interakcije med otrokovim mišljenjem in izkušnjami z materiali, idejami ter ljudmi. Te izkušnje so izziv interesu otrok, njegovemu razumevanju in kulturnemu okolju, iz katerega otrok izhaja (Bredekamp, 1993: 2).

\section{IZKUSTVENO UČENJE ODRASLIH}

Odrasli se uči drugače od otrok, ne zgolj zaradi biološke ali psihološke zrelosti, temveč tudi zato, ker ima več izkušenj in tudi drugačne izkušnje o sebi in svetu, v katerem deluje. Otrokom je izkušnja nekaj, kar se dogaja, odrasel človek pa je tisto, kar je storil, zato je $\mathrm{v}$ trenut$\mathrm{ku}$, ko se znajde $\mathrm{v}$ situaciji, v kateri je njegova izkušnja neuporabna ali zavrnjena, prizadet. »Odrasli vstopajo v izobraževanje z določenimi delovnimi in življenjskimi izkušnjami. Izkušnje postanejo del nas samih. Neprestano se $k$ izkušnjam vračamo in iz njih izhajamo, ko vrednotimo izobraževanje $v$ tem ali onem programu. Če bi kdo ignoriral naše izkušnje, bi se nam zdelo, da ignorira nas same. Izkušnje pri odraslih personalizirajo, ljudje se z njimi identificirajo, postale so del njih samih.« (Krajnc, 1979: 53.) Zavrnitev izkušenj pomeni zavrnitev človeka samega.

Pri izobraževanju odraslih je torej treba upoštevati izkušnje - tako tiste, pridobljene z delom, kot tudi razpršeno življenjsko izkustvo. Značilnosti odraslega, ki vplivajo na učenje in zahtevajo drugačen pristop pri izobraževanju, so po Krajnc (1979): samostojnost, bogate izkušnje, pripravljenost za učenje in izobraževanje, orientiranost na probleme in notranja motivacija. Zato pravi, da mora biti ravnanje $\mathrm{z}$ odraslimi drugačno kot $\mathrm{z}$ otroki. Razlike $\mathrm{v}$ izkušnjah med otroki in odraslimi imajo za učenje tri posledice (Knowles, 1971: 44):

- odrasli prispevajo več $k$ učenju drugih - pri večini vrst učenja so sami vir za učenje,

- odrasli imajo bogatejšo izkustveno podlago, ki jo primerjajo z vedno novimi izkušnjami,

- odrasli imajo veliko število navad in vzorcev mišljenja, ki so močno utrjeni (vgrajeni). 
O identifikaciji z izkušnjami govori tudi Brečko (2003: 49), ki meni, da imajo odrasli sicer bogato zalogo izkušenj, ki so pomemben vir za reševanje problemov, hkrati pa jih prav to bogastvo izkušenj ločuje od otrok in mladine. Na malokaterem področju so odrasli povsem brez izkušenj. Izkušnje in navade pa zelo vplivajo na celotno človekovo vedenje. Izkušnje odraslih so pridobljene z neposrednimi doživetji, zato je takšno izkustvo tudi krepko čustveno obarvano. Odrasli se s svojimi izkušnjami identificirajo. Če njihovih izkušenj ne upoštevamo, jih prezremo ali celo zanikamo, pomeni to napad na njihovo identiteto. S tem lahko pri posamezniku sprožimo konflikt, ki se bo slej kot prej odrazil tudi v zunanjem okolju.

\section{VSEŽIVLJENJSKO UČENJE IN IZOBRAŽEVANJE SKOZI TRNOVSKI MODEL TEMELJNEGA UČENJA (TMTU)}

V Vrtcu Trnovo nas je ob zaznavanju naših posebnosti in izvirnosti, tako vsakega posameznika kot vrtca v celoti, ki smo jih skozi vrsto let skrbno vnašali iz zunanjega okolja, jih $\mathrm{v}$ mnogih razvojnih in raziskovalnih projektih prepletali z vzgojnim delom, strokovnim učenjem in osebnostnim zorenjem, ob sodelovanju številnih strokovnjakov in raziskovalcev s področja predšolske vzgoje, vodila želja smiselno razviti in združiti vse naše znanje in izkušnje v lasten pedagoški model. Povezali smo se z Doro Gobec, ki je več kot deset let razvijala pedagoški model projektnega dela $\mathrm{z}$ lutko v občinskih vrtcih v Milanu. Pred štirimi leti smo skupaj začeli razvijati nov izvirni pedagoški model vrtca, ki smo ga poimenovali Trnovski model temeljnega učenja (v nadaljevanju TMTU). V njem vsi zaposleni soustvarjamo mozaik profesionalnih vedenj, znanj, spretnosti in sposobnosti.

Temeljno učenje predšolskega otroka razumemo kot temelj vseživljenjskega učenja in izobraževanja, v katerem otrok pridobiva kompe- tence učenja in razumevanja: da se zna učiti, pridobivati in uporabljati znanje, informacije in vire informacij, da jih zna ločevati, obdelovati in vključevati v svoje razmišljanje, ustvarjanje, delovanje in komuniciranje. To so kompetence, metodološka orodja, strategije in procesi, s katerimi konstruira znanje in izkušnje ter jih zna uporabljati pri oblikovanju in ustvarjanju svojega okolja ter ustvarjanju novega znanja. Temeljno učenje predšolskega otroka pojmujemo tudi kot temelj trajnostnega razvoja: že v najbolj zgodnjem obdobju učimo otroka temeljnih vrednostnih odnosov do sebe, drugih, sveta, do narave in družbe, kar pomeni, da so vse sestavine trajnostnega razvoja prioriteta predšolske vzgoje. Med njimi so okoljska vzgoja, socialno učenje in komunikacija, kjer otrok vzpostavlja temeljne vrednostne odnose, se uvaja v temeljne človekove dejavnosti, gradi temelje socialnosti, čustvovanja, motivacije in vrednotenja, odnos ljubezni (Gobec, 2008: 55).

Model razvijamo po metodologiji razvojno inovacijskega in akcijskega raziskovanja, splošni didaktični pristop pa je projektno delo z lutko. Edukacijski proces temelji na izkustvenem učenju, kjer otrok raziskuje, išče rešitve, razmišlja, preizkuša in manipulira. Dejavnosti so pestre, izzivajoče, raznovrstne in kakovostne s poudarkom na sproščenem, varnem ozračju v skupini, ki spodbuja otrokovo ustvarjalnost in unikatnost (prav tam). »Uporabljamo pristop, kjer otrok z lastno aktivnostjo konstruira, sklada in harmonizira svojo celotno in celostno podobo sveta $v$ ubranosti s svojo celotno osebnostjo in v celostnem življenjskem in socialnem kontekstu $v$ ponujenih problemskih situacijah in dejavnostih vrtca kakor tudi $v$ realnem življenju $v$ živi interakciji z okoljem. Pri prodiranju v svoje okolje vključujemo v reševanje problema starše, razne strokovnjake, različne poklice, dejavnosti, institucije, medije, svetovni splet. Otroci pridobivajo izkušnje o uporabi različnih načinov komuniciranja, proizvajanja, ustvarjanja, raziskovanja in nadaljnjih novih oblik človekove ustvarjalne prakse 
in se na posebno dejaven način seznanjajo $s$ svojim bližnjim in daljnim okoljem in se vanj vključujejo. Predvsem pa, kar je najpomembnejše - ves čas vidijo smisel, pomen in vrednost svojega delovanja."(Gobec, 2008: 45.)

Naš namen je, da otrok v projektnem delu $z$ lutko spozna, razvije in izrazi vse svoje potenciale in celotno osebnost ter vzpostavi čim bolj aktiven, kreativen, čustveno bogat, socialno angažiran in vrednostno opredeljen odnos do civilizacije in kulture, $v$ kateri živi. To pomeni, da strokovni delavci organiziramo učno situacijo tako, da je otrok maksimalno aktiviran $\mathrm{v}$ svojih zmožnostih, da je čim bolj avtonomen v svojem delovanju, na drugi strani pa, da mu kontekst, v katerem deluje, daje kar največ informacij o kulturi in civilizaciji. Ves čas trajanja projekta vodimo otroke po hevristični poti tako, da ti sami iščejo odgovore: opazujejo, odkrivajo vsak zase in skupaj raznolikosti, jih primerjajo, raziskujejo, postavljajo hipoteze, jih soočajo, argumentirajo, se posvetujejo z eksperti, jih preverjajo na načine, ki jih sami uvajajo, izvajajo eksperimente, izdelujejo naprave, pripomočke ... izkustveno iščejo praktične rešitve. Ob tem se učijo misliti, snovati, delovati, manipulirati, sodelovati in sprejemati odločitve. Celoten projekt postavlja v ospredje otroka ter njegovo aktivacijo in »kreativizacijo« (Gobec, 2008).

\section{UDEJANJANJE VSEŽIVLJENJSKEGA UČENJA IN IZOBRAŽEVANJA}

Na podlagi ugotovljenih potreb po izobraževanju - ustvariti novo kvaliteto strokovnih delavcev z namenom postati notranje motiviran za procesno naravnano razmišljanje in delovanje, ob tem rasti kot posameznik in kot član tima ter dopolnjevati znanje z novimi dognanji znanosti, tehnologije, stroke - integralni del našega razvoja usmerjamo v pridobitev širokega znanja, spretnosti in osebnostnih lastnosti, ki jih potrebujemo, da bi lahko uspešno in kakovostno živeli in delali kot posamezniki in v skupnosti. Proces vseživljenjskega učenja udejanjamo predvsem s tem, da vsi učinkovito delamo kot posamezniki in kot skupina. Naša posebnost oziroma naša svojskost se kaže $\mathrm{v}$ tem, da v prizadevanja za dosego skupnega cilja vključujemo celoten kolegij strokovnih delavcev, predvsem pa, da vsi »dihamo« kot celota. Temeljni pogoj našega razvojnega dela je, da smo $\mathrm{v}$ usposabljanje vključeni vsi strokovni delavci, da se vsi usposabljamo in delujemo po istih metodah in pristopih, po katerih vzgajamo tudi otroke. Bolj kot individualno učenje posameznikov poudarjamo skupno učenje; delujemo timsko, skupaj se učimo, načrtujemo, evalviramo, iščemo in nadgrajujemo svoja znanja. Ob takem načinu učenja pridobivamo tudi interese, značajske poteze, vrednote, odnos do sebe in drugih ter druge osebnostne lastnosti.

Posebno pozornost pri usposabljanju za razvoj svojskega modela namenjamo izobraževanju za razumevanje, spoznavanje, zaznavanje in upoštevanje otrokovih razvojnih značilnosti, temperamentov, stilov učenja, prepoznavanja otrokovih, pa tudi vzgojiteljevih močnih strani in raznolikosti kulturnih okolij, iz katerih otroci izhajajo. Ob tem ozaveščamo dimenzijo konstruktivistične naravnanosti v procesu učenja in vzgojiteljevo vlogo. Proces zajema vse oblike učenja, bodisi formalne bodisi neformalne, naključne ali priložnostne, pomembno vlogo pa ima izkustveno učenje in izobraževanje, saj izhajamo iz prepričanja, da se tako predšolski otrok kot vzgojitelj največ naučita takrat, ko dejavnost opravita sama. Proces uresničujemo $\mathrm{v}$ različnih okoliščinah s ciljem, da se povečajo posameznikovo znanje in spretnosti.

Tako skupaj uresničujemo paradigmatski premik od izobraževanja k učenju, kar pomeni, da težišče premikamo od organiziranega, 
formalnega izobraževanja k učenju, ki izvira iz notranje potrebe tako posameznika kot vrtca, iz življenjskih izkušenj in situacij, kjer se vsebine prepletajo in se zanje odločamo na podlagi lastnega interesa, ki ga označujeta prostovoljnost in veselje do učenja.

\section{IZKUSTVENO UČENJE IN IZOBRAŽEVANJE STROKOVNIH DELAVCEV V VRTCU TRNOVO}

\section{a) Učenje in izobraževanje za profesionalni razvoj}

Ker učenje predšolskega otroka temelji na neposredni aktivnosti in pridobivanju konkretnih izkušenj, tudi strokovni delavci potrebujemo kakovostno izobraževanje, ki nam bo pomagalo ozaveščati pomen izkustvenega učenja in izobraževanja. Usposobiti in razviti je treba tiste lastnosti, ki bodo omogočale, da bomo takšno učenje lahko vodili in ga ustrezno usmerjali. Znati se učiti iz svojih izkušenj in izkušenj drugih je sposobnost, ki je osrednjega pomena za profesionalno rast strokovnih delavcev v vrtcu. Za razumevanje pomena izkustvenega učenja $\mathrm{v}$ vrtcu je pri usposabljanju strokovnih delavcev pomembno, da gremo tudi odrasli skozi poti izkustvenega izobraževanja v neposredni pra$k s i$. Zato je temeljno izhodišče našega učenja in izobraževanja, da strokovni delavci osebnostno in strokovno rastemo skozi lastno delovanje. Ko uvajamo otroka v življenje, naravno okolje, kulturo in civilizacijo (skozi temeljna področja človekovih dejavnosti, kot so se izoblikovale $\mathrm{v}$ zgodovinskem razvoju človeštva: znanost, umetnost, tehnika, tehnologija, informatizacija, komunikacija itd.), je nujno, da tudi sami potujemo skozi identičen spoznavni, izkušenjski, raziskovalni in ustvarjalni proces, kot ga vodimo z otroki. Naše učenje in izobraževanja so problemsko naravnana, izkustvena in usmerjena $v$ kritično razmišljanje in razvijanje miselnih navad, ki sta tudi integralni del našega učnega procesa. $V$ profesionalni razvoj nas vodi stalno ukvarjanje s problemi in poglabljanje v vprašanja, kot so: kako se predšolski otrok uči, kakšno znanje je za otroka smiselno, kakšna vseživljenjsko pomembna temeljna znanja potrebuje otrok, kako mu strokovni delavci v vrtcu lahko pomagamo.

Bistveni sprožilec naše poklicne rasti je kritična refleksija in odgovarjanje na temeljna vprašanja, ki si jih zastavljamo, saj pridobivanje poklicnih izkušenj ne vodi nujno k poklicni rasti in višjim pojmovanjem učenja; učinkovito je osmišljanje oziroma refleksija teh izkušenj. Izkustveno učenje je kontinuiran proces, ki zajema izkušnje, refleksijo in delovanje. Stalno

Na razvojnih seminarjih odrasli na enake načine kot tudi otroci aktivno in samostojno odkrivamo probleme in vprašanja prek akcijskega raziskovanja, projektnega dela in terenskih vaj, katerim je skupno izkustveno učenje, proces, ki se odvija skozi faze poročanja, načrtovanja, aktivnosti, analize, povzetka in evalvacije. Do odgovorov na vprašanja in dileme, ki se porajajo, prihajamo po identičnih poteh in pristopih, po katerih sami vodimo otroke, vendar na ravni svojih izkušenj, izobrazbe in poklicne kompetentnosti. Sproti razčlenjujemo vsakdanje poklicne izkušnje in se iz njih učimo. Razpravljamo o skupnih projektih, svoje interpretacije in dileme pa prediskutiramo in obogatimo s pomočjo svojih kolegov. V izobraževalnem procesu sodelujemo vsi strokovni delavci, saj le tako lahko tisto, kar delamo, mislimo in občutimo, združujemo v smiselno celoto. Tako povezujemo praktične izkušnje s teoretičnim znanjem, kar nam omogoča prenos teorije v prakso in spodbuja učenje avtonomnega delovanja. Mijoč (2000: 71) meni, da praksa sama po sebi še ne pomeni izkušnje, izkušnje se spremenijo v nova spoznanja šele s teorijo. Torej nam teorija pomaga izkušnje spremeniti v nova spoznanja. Praksa pa nam omogoča nova spoznanja, ko o njej razmišljamo in jo povežemo z znanji, teorijo in razmišljanjem drugih. To razmišljanje prenašamo med seboj, tako da skupaj razpravljamo $\mathrm{v}$ sproščenem ozračju, kjer smo vsi enakopravni. Šele v odnosih z drugimi prepoznavamo, spoznavamo, uravnavamo samega sebe in ob raznolikosti medsebojnih odnosov v delovnem procesu osmišljamo tudi svoje poklicno poslanstvo. 
reflektiranje izkušenj, tako osebno kot skupinsko, prepletanje izkušenj s teorijo in proces nenehnega učenja nam omogočajo stalno rast na profesionalni in osebni ravni.

\section{b) Učenje in izobraževanje za osebnostni razvoj}

Ker se odrasli s svojimi izkušnjami identificiramo, $\mathrm{v}$ našem izobraževalnem procesu poseben pomen dajemo vsem izkušnjam strokovnih delavcev, ne le delovnim, ampak tudi življenjskim, in jih $\mathrm{v}$ procesu izobraževanja upoštevamo. Upoštevanje naših osebnih izkušenj vnaša $v$ skupinsko učenje nove vrednote. Ko se upoštevajo naše delovne in življenjske izkušnje, dobimo občutek, da nekaj znamo, da nekaj vemo, da to naše znanje tudi drugim v skupini nekaj pomeni. Cilj dela za osebnostno rast je po Dori Gobec (2000) pridobivati vpoglede v globlje razumevanje svojega subjektivnega doživljanja in odzivanja na življenjske situacije in poglabljanje svojega vrednostnega odnosa do življenjskih izkušenj in refleksij - rasti prek literature, seminarjev in stikov z umetniškimi deli.

\section{c) Učenje in izobraževanje za socialni razvoj}

Učimo in izobražujemo se individualno, predvsem pa skozi socialno interakcijo, kjer skupaj z drugimi izumljamo, postavljamo hipoteze, predvidevamo, upravljamo in organiziramo informacije ter konstruiramo (nadgrajujemo) znanje. Izmenjujemo ideje in refleksije, svoje subjektivne teorije o učenju, odnosih, vzrokih raznih pojavov pa stalno primerjamo $\mathrm{z}$ znanstvenimi teorijami. Učimo se od drugega, učimo se prek teorij, ki jih spoznavamo v knjigah, študiramo literaturo, spremljamo umetniške in kulturne dogodke, iščemo različne vire znanja; učimo se vsi in od vseh. Ustvarjamo prostor svobode in različnosti, demokratičnega odločanja in izbire. Prav klimi/kulturi in odnosom v vrtcu namenjamo posebno pozornost, spodbudnemu in varnemu prostoru za dvom, napake, drugač- no razmišljanje. Skupaj ustvarjamo ustrezno vzdušje za izobraževanje in usposabljanje ter gradimo miselnost, da je stalno izobraževanje in usposabljanje nujen pogoj za poklicni in osebnostni razvoj vsakega posameznika.

Strokovni delavci za svoje učenje in izobraževanje potrebujemo nove izkušnje, a se ne učimo iz izkušenj samih, temveč iz refleksije o njih. Učimo se, ko nam uspe pogledati na izkušnje $\mathrm{z}$ različnih zornih kotov, $\mathrm{s}$ katerimi osvetlimo subjektivne teorije o vzgojno-izobraževalnem polju, ki so v ozadju našega ravnanja.

\section{RAZISKAVA O IZKUSTVENEM UČENIU IN IZOBRAŽEVANIU}

Raziskava je bila namenjena evalvaciji programa usposabljanja strokovnih delavcev za razvoj svojskega modela v Vrtcu Trnovo. Želeli smo ugotoviti, kakšno vlogo ima izkustveno učenje in izobraževanje oziroma kako izbrane strokovne delavke v vrtcu, kjer ima izkustveno učenje središčno vlogo $\mathrm{v}$ procesu učenja in izobraževanja, razumejo izkustveno učenje in kako ga po njihovem mnenju uresničujejo. V nadaljevanju predstavljam del ugotovitev na naslednja raziskovalna vprašanja:

1. Kaj strokovne delavke razumejo pod izkustvenim učenjem?

2. Na kakšne načine se skozi delovni proces izkustveno učijo in izobražujejo?

3. V kakšnih okoliščinah lahko v vrtcu uporabljajo svoje izkustveno pridobljeno znanje?

\section{METODOLOGIJA}

Podatke smo zbrali s skupinskim intervjujem, ki je poleg vprašanja o razumevanju izkustvenega učenja zajemal še vprašanja o načinih izkustvenega učenja in uporabnosti izkustveno pridobljenih znanj. Vprašanja so bila odprtega tipa, kar je intervjuvankam omogočalo, da predstavijo svoja osebna pojmovanja, nam pa kvalitativno analizo odgovorov. Pri obdelavi podatkov smo odgovore strokovnih delavk najprej 
kategorizirali. Pri kategorizaciji smo izhajali iz prejetih odgovorov. $\mathrm{V}$ raziskavo smo zajeli pet strokovnih delavk, ki v istem vrtcu vodijo otroke različnih starosti (tri do štiri let, štiri do pet let, pet do šest let, dve do šest let in tri do pet let). Izbrane strokovne delavke se skozi vse leto usposabljajo na seminarjih za razvoj svojskega modela (TMTU), v projekt pa so vključene od njegovega začetka, zdaj teče četrto leto.

\section{ANALIZA ODGOVOROV}

Kategorija: razumevanje izkustvenega učenja Najpogostejši odgovori na vprašanje Kaj razumete pod izkustvenim učenjem? so bili: lastna aktivnost, aktiven otrok, uporaba vseh čutil, praktična znanja, informacije, razumevanje in uporaba, vedenje, znajti se v različnih situacijah, zmožnost reševanja problemov, trajno znanje.

Kategorijo sestavljajo vse faze Kolbovega cikla izkustvenega učenja.

\section{Opis faz izkustvenega učenja}

- Fazo konkretne izkušnje (dojemanje) opisujejo odgovori, kot so: na lastnem izkustvu, lastno učenje, ko sam nekaj narediš, učenje z uporabo čutil, praktično učenje, konkretna izkušnja.

- Fazo razmišljujočega opazovanja opisujejo odgovori, kot so: opazovanje, razmišljanje, kako boš nekaj naredil, predvidevanje, primerjanje, razmišljanje o tem, kaj se bo zgodilo, ne le opazovanje, tudi akcija.

- Fazo abstraktne konceptualizacije (razumevanje) opisujejo odgovori, kot so: z lastno aktivnostjo do spoznanj, celostno razmišljanje, sklepanje, ugotavljanje, prihajanje do rešitev, prihajanje do vpogleda, nova spoznanja.

- Fazo aktivnega eksperimentiranja (preizkušanje novih spoznanj) opisujejo odgovori, kot so: lastna aktivnost otroka, poizkušanje, preizkušanje, preverjanje.

- Pod razno so navedeni še naslednji posamični odgovori: predhodne izkušnje, preverjanje teorije v praksi, aktivnost, krožen proces, ponavljanje, doživetje, refleksivnost.

Za kategoriziranje odgovorov v posamezne faze izkustvenega učenja smo se odločili, ker je bilo v odgovorih strokovnih delavk, zajetih v raziskavo, opaziti vse faze in elemente izkustvenega učenja z zaključenim krogom tega učenja. Faze izkustvenega učenja so najbolje prikazane $\mathrm{v}$ Kolbovem ciklu izkustvenega učenja kot sklenjenega procesa $\mathrm{s}$ štirimi stopnjami: od konkretne izkušnje do opazovanja, razmišljanja, oblikovanja abstraktnih pojmov in preverjanja pojmov v novih situacijah. Prva stopnja pomeni neposredno izkušnjo, s pomočjo katere sprejemamo informacije iz okolja. Sledi ji opazovanje, ki ga spremlja razmišljanje. Abstraktna konceptualizacija pomeni, da nekaj razumemo, da razvijemo teorijo. Sledi stopnja preizkušanja novih spoznanj in posplošitev, kar lahko spet privede do nove izkušnje (Mijoč, 1995).

Iz odgovorov sklepamo, da strokovne delavke razumejo izkustveno učenje kot metodo učenja, za katero je vsekakor značilno neposredno srečanje s konkretno izkušnjo, s poudarkom tako na aktivnem eksperimentiranju kot tudi na razmišljujočem opazovanju in lastni aktivnosti. Nadalje sklepamo, da izkustveno učenje strokovne delavke razumejo kot učenje, kjer se najbolje učimo, če sami nekaj naredimo. Izkustveno učenje povezujejo s predhodnimi izkušnjami, tako svojimi kot tudi otrokovimi, kot priložnost za višjo kakovost pridobivanja novih znanj in trajnostjo znanj, priložnost za oblikovanje veščin in spretnosti, samostojnost, aktivno in celostno vpletenost $\mathrm{v}$ proces, sodelovalnost ter nujno refleksivno odzivnost. Odgovori torej nakazujejo različne poglede na izkustveno učenje od poznavanja prek razumevanja in uporabe pojma, povezujejo pa ga tudi s krožnim procesom. Vsem fazam izkustvenega učenja dajejo velik pomen, še posebno konkretni izkušnji, saj se ta tudi otrokom mnogo trajneje vtisne v spomin kot kakršnokoli drugačno učenje. Velik pomen pri izkustvenem učenju pripisujejo še uporabi čutil, saj je učenje, v katerem imajo otroci 
možnost sodelovati z več čutili, učinkovitejše, zanj so otroci tudi mnogo bolj motivirani.

Sklepamo lahko, da strokovne delavke izkustveno učenje razumejo kot celosten pristop, ki ga je mogoče vedno in povsod uresničevati na vseh ravneh vzgojno-izobraževalne prakse. Vsekakor razumejo izkustveno učenje kot učenje, ki se dogaja skozi vse življenjsko obdobje; tudi odrasli Vzgojiteljice se ucijo predvsem od otrok, sodelavcev, staršev, na delavnicah, terenskem delu in iz knjig. se skozi svoje izkušnje največ in najbolje naučimo.

\section{Kategorija: načini izkustvenega učenja}

$\mathrm{V}$ odgovorih na vprašanje $\mathrm{Na}$ kakšne načine se skozi delovni proces izkustveno učite in izobražujete? so strokovne delavke $\mathrm{v}$ ospredje postavile predvsem vire za učenje: učenje od otrok, učenje od sodelavcev, učenje od staršev, učenje od zunanjih sodelavcev in drugo.

\section{Opis virov za izkustveno učenje}

- Učenje od otrok $v$ skupini - zajeti so odgovori, kot so: že od dojenčkov se veliko naučimo, ko otroci »notri padejo«, ko ti otrok pokaže kako, največ se naučim skozi odnose.

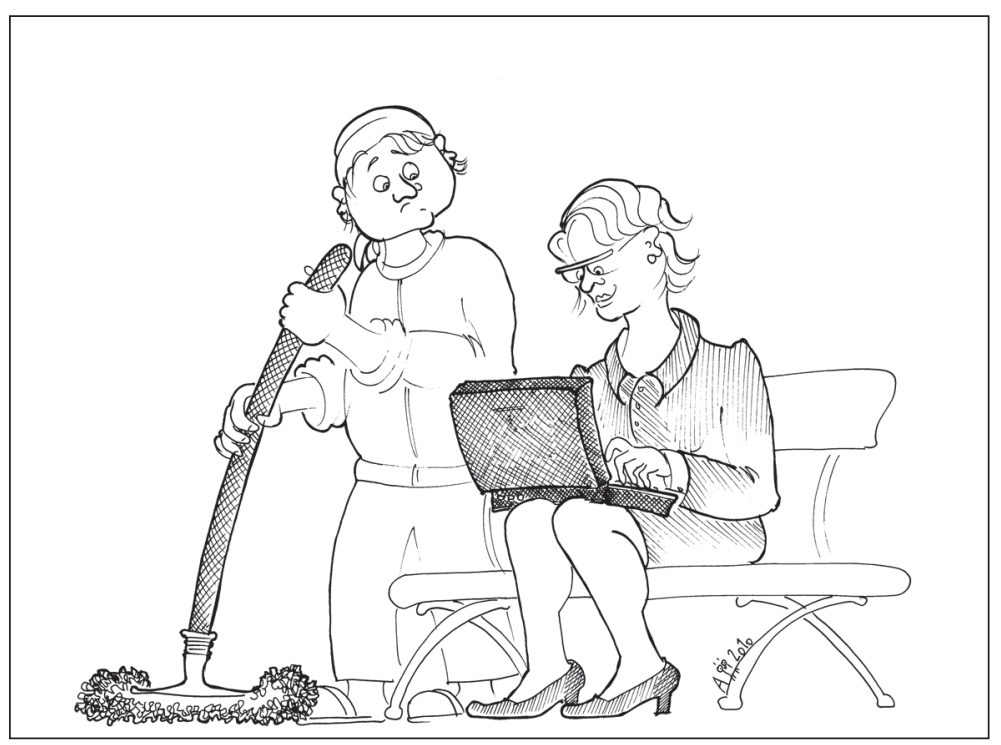

- Skozi učenje od sodelavcev - zajeti so odgovori, kot so: učenje drug od drugega, timsko delo, skupno razvojno delo, medsebojni pogovori.

- Skozi učenje od staršev otrok - zajeti so odgovori, kot so: od staršev, starši veliko participirajo, s sodelovanjem s starši.

- Skozi učenje od zunanjih sodelavcev - zajeti so odgovori, kot so: od strokovnjakov, $\mathrm{s}$ katerimi sodelujemo.

- Pod razno so navedeni še naslednji posamični odgovori: razvojni seminarji, terensko delo, naravno okolje, iz raznih knjig, na praktičnih delavnicah, s samoizobraževanjem, $\mathrm{z}$ brskanjem po internetu, področje IKT, iz literature, kjer preverjaš svoje znanje, prek zaznavanja preverjaš odnose, povratne informacije, skozi napake, učenje skozi refleksije. Za to kategorizacijo smo se odločili zato, ker odgovori strokovnih delavk kažejo na to, da dajejo velik poudarek tako učenju od otrok kot tudi učenju od sodelavcev, staršev otrok in zunanjih strokovnjakov. Ker strokovne delavke največ delovnega časa posvetijo prav otrokom, je logična posledica, da na njihovo izkustveno učenje močno vplivajo prav otroci. S svojo strokovno naravnanostjo podpirajo in vodijo otroka skozi takšna izkustva, ki oblikujejo temelj njegovim zmožnostim za osvajanje, ohranjanje, oblikovanje in preoblikovanje sveta, ob tem pa se tudi same veliko naučijo od otrok. Skozi delovni proces se izkustveno veliko učijo od svojih sodelavk in sodelavcev, saj imajo ti bogato zalogo izkušenj in so pomemben vir za reševanje problemov. Skupaj razglabljajo, ugotavljajo, reflektirajo izkušnje ter iščejo pomoč in možne rešitve. Gre za učenje na delovnem mestu, kjer se prepletajo refleksije in uporaba »praktičnih teorij« posameznih strokovnih delavcev.

Kot velik vir izkustveno pridobljenih znanj strokovne delavke omenjajo tudi razvojne seminarje. Pravijo, da so se z uvajanjem svojskega modela bistveno spremenili proces dela, odnos do otrok in odnos do sodelavcev, pa tudi do staršev otrok, soustvarjalcev našega modela. Veliko več 
je sodelovalnega učenja, skupnega načrtovanja, skupnega raziskovanja, eksperimentiranja in refleksij. Prav skupno učenje je značilnost našega razvojnega dela; delujemo timsko, skupaj se učimo, načrtujemo, evalviramo, iščemo in nadgrajujemo svoja znanja. Raznolikost znanja in izkustev povečuje našo sposobnost za reševanje problemov in s tem za obvladovanje vsakodnevnih sprememb. Strokovne delavke se izkustveno učijo tudi iz študija različne literature, prek teorij, ki jih spoznavajo iz knjig, praktičnih in terenskih delavnic, spremljanja umetniških, kulturnih del in interneta ter informacijsko-komunikacijske tehnologije.

Znati se učiti iz svojih izkušenj in izkušenj drugih je osrednjega pomena za profesionalno rast strokovnega delavca.

\section{Kategorija: uporabnost izkustveno pridobljenih znanj}

Najpogostejši odgovori na vprašanje Kako svoje izkustveno pridobljeno znanje uporabljate v praksi? so bili: uporabim ga na enak način, kot sem ga sama pridobila, poskrbim, da otroci sami poiščejo informacije, kar dobro deluje pri meni, znam prenesti na otroke, skozi leta sem se naučila podajati znanje na različne načine, iz pridobljenih izkušenj znam bolj prisluhniti, poslušati in se nato odzvati, tako znanje lahko uporabim vsepovsod, učiti se iz izkušenj drugih, organiziranje učnih situacij.

\section{Opis uporabnosti izkustveno pridobljenih znanj}

- Učenje za profesionalni razvoj - zajeti so odgovori, kot so: uporaba pridobljenih znanj na različnih nivojih, podajanje znanja na različne načine, prilagajanje različnim situacijam, spodbujanje otrok k izkustvenemu učenju, priprava situacij, kjer lahko otroci sami poiščejo informacije, ponujanje otrokom različnega materiala za raziskovanje, manipuliranje $\mathrm{z}$ materiali, iskanje informacij na internetu, spodbujanje otrok $\mathrm{k}$ samostojnemu delu, $\mathrm{k}$ preverjanju informacij, delovati iz tistih izku- šenj, ki si jih pridobil, upoštevanje izkušenj drugih, večji posluh za otroke, boljše opazovanje, razmišljanje o otrocih, reflektiranje.

- Učenje za osebnostni razvoj - zajeti so odgovori, kot so: zadovoljstvo ob delu, osebnostne spremembe, pretekle izkušnje.

- Učenje za socialni razvoj - zajeti so odgovori, kot so: učenje od sodelavk in prenos tako pridobljenih znanj na otroke, podajanje izkustveno pridobljenih znanj svojim sodelavkam - učenje drug od drugega, vživljanje v drugega, povezovanje in sodelovanje skupin med seboj.

Za tako kategorizacijo smo se odločili zato, ker so tudi strokovne delavke razmišljale $\mathrm{v}$ tej smeri. Njihovi odgovori kažejo na to, da svoje izkustveno pridobljeno znanje lahko uporabijo vsepovsod, kjer so aktivno angažirane; tako na profesionalnem področju kot tudi na osebnostnem in socialnem področju. Iz odgovorov je mogoče razbrati, da strokovne delavke novo znanje in izkušnje ustvarjajo predvsem skozi procesno naravnano usposabljanje, kjer v socialni interakciji svoji zalogi nenehno dodajajo novo znanje, ki ga pridobijo z novimi izkušnjami ter ga sproti uvajajo in preizkušajo $v$ delu z otroki. Svoje izkustveno pridobljeno znanje uporabljajo zlasti pri spodbujanju aktivne vloge otrok pri učenju, razvijanju samostojnosti in samoorganiziranosti ter razvoju veščin, $k i$ jih bodo otroci potrebovali tudi kasneje v življenju, kot so sposobnost izbiranja, odločanja, prevzemanja odgovornosti, sodelovanja $\mathrm{z}$ drugimi pa tudi aktivne angažiranost pri učenju. Zavedajo se, da je njihova vloga, osredotočena na otroka, odločilna $\mathrm{v}$ procesu izkustvenega učenja otrok in da je za uspešnost učenja otrok pomembna tudi njihova sposobnost za učenje. Priložnost za uporabo svojega znanja v praksi vidijo tudi v učenju drug od drugega, kjer izkustveno znanje ne le pridobivajo od drugih, ampak so lahko tudi same vir znanja za drugega; 
skozi lastne primere svoja pridobljena znanja posredujejo drugim sodelavcem, velikokrat tudi staršem otrok; ob tem pa odkrivajo in razvijajo lastne potenciale in bogatijo sebe.

Profesionalni razvoj razumejo kot proces vseživljenjskega izkustvenega učenja, pri katerem razvijajo (osmišljajo) svoja pojmovanja in spreminjajo svojo prakso poučevanja; gre za proces, ki vključuje osebnostno, poklicno in socialno dimenzijo in pomeni napredovanje $\mathrm{v}$ smeri kritičnega, neodvisnega, odgovornega odločanja in ravnanja.

\section{ZAKLJUČEK}

V Vrtcu Trnovo z izkustvenim učenjem sledimo smernicam sodobnega poučevanja $\mathrm{v}$ smislu aktivnega vključevanja učečih se posameznikov $\mathrm{v}$ proces učenja. $\mathrm{V}$ izkustvenem učenju vidimo priložnost za večjo aktivnost v procesu učenja ter za večjo trajnost in kakovost znanj. Vrednost izkustvenega izobraževanja vidimo v ustvarjalnem načrtovanju skupinskega učnega procesa, ki se $\mathrm{v}$ interakciji z udeleženci spet ustvarjalno dopolnjuje in udejanja. Gre predvsem za transformacijo spoznanj na podlagi novih izkušenj. S takšnim pristopom dosegamo trajnejše znanje ter drugačen načina razmišljanja in delovanja. Pomembno je, da znamo praktične izkušnje povezati s teoretičnim znanjem, kar omogoča prenos teorije $\mathrm{v}$ prakso in spodbuja učenje avtonomnega delovanja. Tako naše znanje $\mathrm{v}$ vrtcu postaja še kakovostnejše, širše, bogatejše in uporabnejše. Tudi ob vpogledu v izkustveno učenje izbranih strokovnih delavk, ki so vključene v usposabljanje za razvoj svojskega modela v vrtcu, je očitno, da takšno učenje razumejo kot celosten pristop, ki ga je mogoče vedno in ob vseh priložnostih uresničevati na vseh ravneh vzgojno-izobraževalne prakse. Vsakdanje življenjske situacije v vrtcu jim ponujajo veliko možnosti za izkustveno učenje; vpletenost $\mathrm{v}$ izkušnjo pa jim pomaga pridobivati veščine in znanja, ki jih ljudje v svetu nenehnih sprememb vedno bolj potrebujemo: fleksibilnost, empatijo, zmožnost reševanja problemov v nepredvidljivih, kompleksnih situacijah, sposobnost komunikacije in sodelovanja, zmožnost celostnega dojemanja, sinteze, integracije idr. Pri svojem delu vidijo veliko priložnosti za aktivno eksperimentiranje in razmišljujoče opazovanje - tako pri sebi kot pri otrocih. Svoje pridobljeno znanje znajo kakovostno in učinkovito uporabiti v različnih situacijah, s čimer pripomorejo k večji dinamičnosti in kakovosti vzgojno-izobraževalnega dela ter $\mathrm{k}$ trajnejšemu in uporabnejšemu znanju. Tako otrokovemu kot tudi svojemu.

\section{LITERATURA}

Bredekamp, S. (1993). Developmentally Approropriate Practice in Early Childhood Programs Serving Children From Birth Through Age 8. Washington D.C: National Association for the Education of Young Children.

Bredekamp, S., Rosegrant, T. (1993). Reaching Potentials: Transforming Early chilhood Curriculum and Assessment. Volume 2. Washington D.C: National Association for the Education of Young Children.

Bečaj, J. (2006). »Pot do kakovostnih odnosov«. Š olski razgledi, 17.

Gobec, D. (2008). Elementi pedagogike skupnosti v Trnovskem modelu temeljnega učenja vrtca Trnovo. Zaključno delo iz Pedagogike skupnosti in metode Agazzi, Učiteljski fakultet Sveučilišta u Zagrebu, EDU educazioneunita, Vrtič Zraka sunca, Križevci.

Jarvis, P. (2003). »Učenje iz izkušenj«. Andragoška spoznanja, 9, 2: 19-29.

Knowles, M. (1971). The modern practice of adult education. New York.

Krajnc A. (1979). Metode izobraževanja odraslih. Ljubljana: Andragoška didaktika.

Krajnc, A. et. al. (1998). Vseživljenjsko izobraževanje in vseživljenjsko učenje. Zbirka študije in raziskave. Ljubljana: Andragoški center Slovenije.

Marentič Požarnik, B. (1992). »Izkustveno učenje modna muha, skupek tehnik ali alternativni model pomembnega učenja? « Sodobna pedagogika, 43, 1-2: $1-15$.

Mijoč, N. (1995). Izkustveno učenje odraslih glede na sociokulturni sloj in poklicno strukturo. Doktorska disertacija. Ljubljana

Mijoč, N. (2000). »Odrasli se učimo z delovanjem. Izkušnje so bistvo učenja«. Andragoška spoznanja, 3, 1: 68-74. 